\title{
Efficacy Test of Trichoben Vaccine Administered to Calves at Different Intervals between Vaccination and Re-Vaccination
}

\author{
A. RYBNIKÁŘ, E. OBOŘILOVÁ, R. HEDBÁVNÝ \\ Bioveta, a.s., Ivanovice na Hané, Czech Republic
}

Received May 24, 2007

Accepted February 14, 2008

\begin{abstract}
Rybnikář A., E. Obořilová, R. Hedbávný: Efficacy Test of Trichoben Vaccine Administered to Calves at Different Intervals between Vaccination and Re-Vaccination. Acta Vet. Brno 2008, 77: 239-243.

The aim of the study was to test a possible extension of the period between vaccination and revaccination with the live Trichoben vaccine (Bioveta, a.s., Czech Republic). The calves $(\mathrm{n}=61)$ were vaccinated intramuscularly. The intervals between vaccination and re-vaccination were $3,5,7,10,14$ or 28 days. Another group of calves $(n=16)$ was vaccinated once with a double dose of the vaccine. The protective immunity against experimental infection with a virulent Trichophyton verrucosum CCM F-650 strain was investigated in animals one month after the last vaccination and compared with a group of non-vaccinated controls $(n=16)$. Clinical results were evaluated and compared using balanced two-way-ANOVA. The level of post-vaccination immunity in cattle after re-vaccination was sufficient when the intervals were 5, 7, 10, 14 and 28 days. One-time injection of a double prophylactic dose of the vaccine and a 3-day interval between vaccinations reduced the immunity and vaccine efficacy to an unsatisfactory degree. There were significant differences between the groups of calves vaccinated using an interval longer than 5 days, and the group vaccinated once with a double dose, and the group with a 3-day interval between vaccinations. The level of post-vaccination immunity in cattle after re-vaccination at the commonly used interval of 10 - 14 days was identical with the immunity achieved when the interval was reduced to 5 or 7 days or extended up to 28 days. The extension of the interval between vaccinations to 5 - 28 days is recommended for using the Trichoben vaccine in veterinary practice.
\end{abstract}

Cattle, post-vaccination immunity, challenge, Trichophyton verrucosum

Vaccination of cattle against ringworm has been widely carried out in common veterinary practice since 1971 (Sarkisov 1979). Live vaccines yielded the best results under both experimental and practical conditions (Gudding and Lund 1995). It was found that a single dose of these vaccines is not sufficient for the development of satisfactory immunity against trichophytosis; double administration of these biopreparations has to be done to obtain convenient vaccine efficacy (Rybnikář et al. 1998). The interval between vaccination and re-vaccination is mostly from 10 to 14 days in registered antimycotic vaccines. In our experiment the influence of shortening and prolongation of this interval between both vaccinations on the post-vaccination immunity level was investigated.

\section{Materials and Methods}

The experiments were carried out on 93 calves of Holstein breed aged between 2 and 86 days, divided uniformly into eight experimental groups ( $\mathrm{n}=8$ to 16 ) according to age. The young cattle came from breeding facilities with no incidence of trichophytosis in the past. The animals in seven groups were vaccinated with the commercial live lyophilized Trichoben inj. sicc. ad us. vet. vaccine against trichophytosis produced by Bioveta, a.s., Czech Republic. Two prophylactic doses of $2.5 \mathrm{ml}$ were given to calves intramuscularly into the gluteal muscle. The interval between the vaccination and re-vaccination was 3 days (group $2 ; n=8$ ), 5 days (group $3 ; n=11$ ), 7 days (group $4 ; \mathrm{n}=8$ ), 10 days (group $5 ; \mathrm{n}=15$ ), 14 days (group $6 ; \mathrm{n}=11$ ) and 28 days (group $7 ; \mathrm{n}=8$ ). The animals of group $1(\mathrm{n}=16)$ were vaccinated once using a dose of $5 \mathrm{ml}$.

One month after the last vaccination all calves including the non-vaccinated controls (group $8 ; n=13$ ) were challenged using the method described by Rybnikáŕ et al. (1993). The challenge dose of Trichophyton

Address for correspondence:

RNDr. Alois Rybnikár

Bioveta, a.s., 68323 Ivanovice na Hané

Czech Republic.

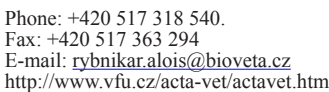




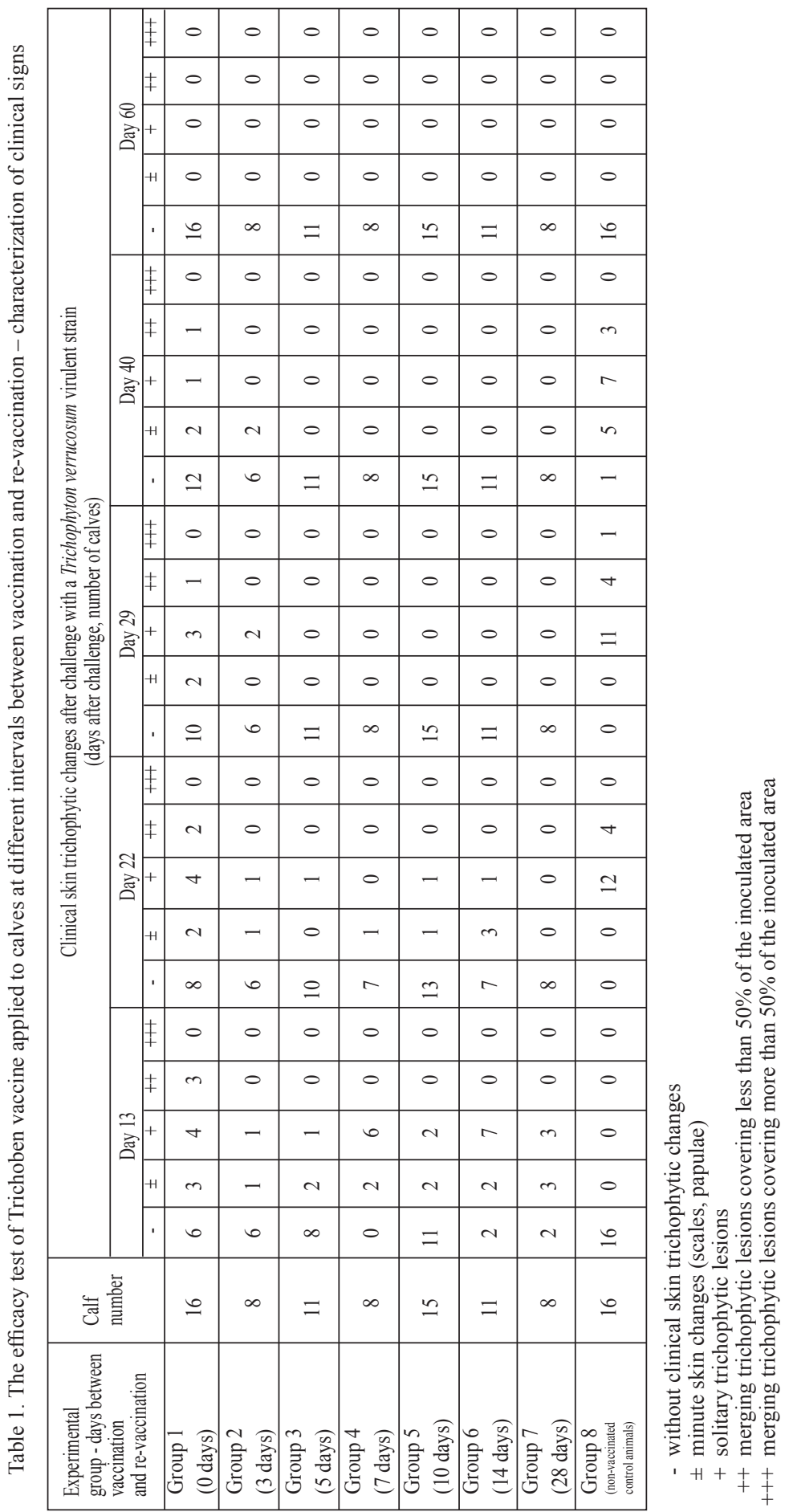


verrucosum CCM F-650 virulent culture isolated originally from cattle with clinical mycotic changes was 1 million of CFU per animal in this experiment. Examination of the inoculated skin area for the presence of clinical mycotic changes (i.e., the efficacy test) followed for 60 days. Samples of positive skin changes were collected and cultured on Sabouraud agar with actidion and chloramphenicol.

Current provisions of animal protection laws were followed during these experiments. Balanced two-way ANOVA was used in statistical evaluation of the challenge results.

\section{Results}

The results of the experiment are shown in Table 1 and in Fig. 1.
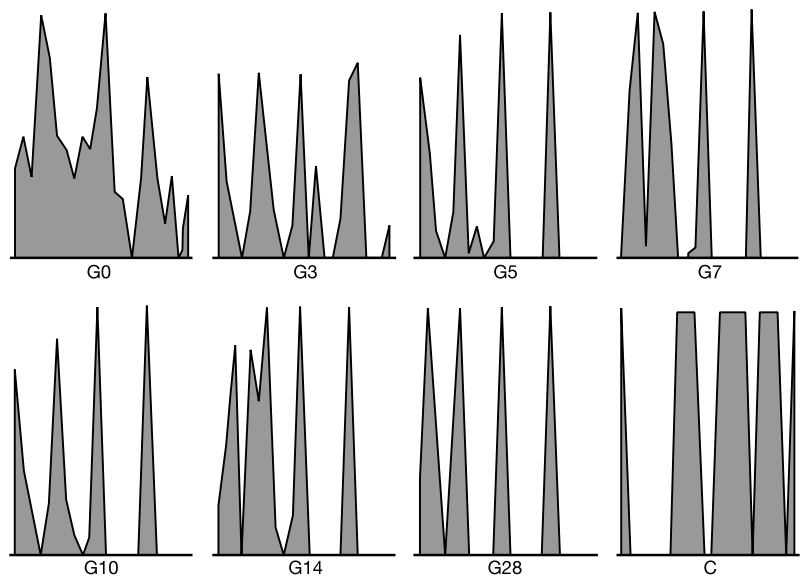

Fig. 1. The efficacy test of Trichoben vaccine applied to calves in different intervals between vaccination and re-vaccination - profiled graph
G0 one-time application of a double prophylactic dose
G3 3 days between vaccination and re-vaccination
G5 5 days between vaccination and re-vaccination
G7 7 days between vaccination and re-vaccination
G10 10 days between vaccination and re-vaccination
G14 14 days between vaccination and re-vaccination
G28 28 days between vaccination and re-vaccination
C non-vaccinated controls

The animals re-vaccinated at intervals of 5, 7, 10, 14 and 28 days, respectively, (group 3 - 7) after the second vaccination developed a satisfactory degree of post-vaccination immunity which protected all of them against experimental infection with the virulent Trichophyton verrucosum strain. Following the challenge, there were no clinical signs of ringworm in the calves or only minute ones, such as scales, papulae or solitary trichophytic lesions. These superficial changes occurred sooner (i.e., already on the $13^{\text {th }}$ day) than in control animals, but their duration was short (i.e., no longer than till the $29^{\text {th }}$ day after challenge in the animals of groups 3 - 7).

The degree of immunity in the animals that received vaccination and re-vaccination at the same time (group 1) or at the interval of 3 days (group 2) was lower than in the calves of the groups mentioned above. Merging trichophytic lesions covering less than $50 \%$ of the inoculated area occurred in some animals of these two experimental groups. Clinical skin changes persisted longer, too. They disappeared in all calves within day 55, or day 44 after challenge, respectively.

The onset of the first clinical signs was recorded later (i.e., on the $22^{\text {nd }}$ day) in the control non-vaccinated animals (group 8) than in the vaccinated ones, but the course of the 
mycotic infection was more severe in them. All animals showed typical clinical signs of trichophytosis affecting even the deep skin layers, i.e., the extent of trichophytic changes ranged from solitary trichophytic lesions to merging trichophytic lesions covering more than $50 \%$ of the inoculated area. These changes persisted till the $47^{\text {th }}$ day in more than $50 \%$ of the control calves and disappeared within the $60^{\text {th }}$ day in all of them.

The results presented above were evaluated by statistical analyses that demonstrated the development of immunity after vaccination in all vaccinated groups compared to non-vaccinated control animals. There were no significant differences in the immunity level between the groups of calves vaccinated and re-vaccinated using an interval longer than 5 days. Significant differences in immunity were found among these groups and the group of calves vaccinated once with a double dose and the group with a 3-day interval between vaccinations.

The challenge Trichophyton verrucosum strain was detected in all clinically positive animals.

\section{Discussion}

Problems concerning the immunity rise after a single administration of the vaccine against trichophytosis in cattle were dealt with in a previous study (Rybnikár et al. 1998). The Trichoben vaccine injected once in a double prophylactic dose yielded satisfactory immunity only in $50 \%$ of calves. When the same total amount of the vaccine was divided into two prophylactic doses administered according to the Package Insert at a 13-day interval, sufficient protection against experimental infection was demonstrated in all immunized calves. Similar results were also obtained in the present work. Single administration of Trichoben proved to be unsatisfactory. Long-term mycotic changes occurred in $25 \%$ of calves after challenge with the Trichophyton verrucosum virulent strain. This lower ratio of vaccinated animals with insufficient immunity and the more moderate course of illness in the control non-vaccinated animals is mainly due to the administration of a five times lower challenge dose of dermatophytic culture than in the previous experiment. After the immunization of calves with the same preparation according to the Package Insert with limit intervals of 10 or 14 days between vaccination and re-vaccination, satisfactory immunity was achieved in all animals, which confirms the foregoing results and our thirty years' experience with the live vaccine in veterinary practice.

The Russian vaccine LTF-130 against trichophytosis in cattle injected once at a double dose did not raise sufficient immunity response, either (Golovina and Zharkov 1984). Sarkisov (1979) regards a single vaccination against trichophytosis unacceptable and thus explains the cases of insufficient efficacy of LTF-130 in practice. This vaccine must be administered twice at the interval of 10 to 14 days (Sarkisov et al. 1976). For other mycotic vaccines for cattle the following period between vaccination and re-vaccination is recommended: for the Polish vaccines Trichovac 10 - 12 days (Wawrzkiewicz and Wawrzkiewicz 1984) and Bovitrichovac 10 - 14 days (Wawrzkiewicz and Chrol 1977); for the Russian Vermet vaccine 10 - 16 days (Sarkisov et al. 2000); and for the German Insol Trichophyton vaccine 14 days (Bratberg et al. 1999).

Our new results proved that the reduction of the interval between vaccinations with Trichoben to 5 or 7 days or its extension up to 28 days did not influence negatively the level of post-vaccination immunity. However, when re-vaccination was done 3 days after the vaccination, trichophytosis occurred in two calves of eight after challenge with the $T$. verrucosum virulent strain. The protective efficacy of the vaccine was lower than in the case of longer time intervals between vaccinations. The efficacy of the vaccine injected in this way was unsatisfactory, same as in the case of its one-time administration. This indicates that the rise of immunity in vaccinated animals is strongly influenced by the survival of the vaccination strain $T$. verrucosum at the site of its injection, i.e. in the inoculated muscle (Hejtmánek et al. 1986). 
The results of this work may be used in general veterinary practice. We recommend changing the Trichoben vaccination scheme from the current interval of 10 - 14 days between vaccinations to 5 - 28 days. This should bring numerous organisational advantages in cattle husbandry. Of particular importance are shorter terms for re-vaccination, which enable a faster rise of immunity and thus earlier protection of cattle against this dangerous infection. We recommend testing the given vaccination scheme with other mycotic vaccines as well.

\section{Zkouška účinnosti vakcíny Trichoben aplikované telatům v různých intervalech mezi vakcinací a revakcinací}

Cílem studie bylo ověřit možnost rozšíření intervalu mezi vakcinací a revakcinací u živé vakcíny Trichoben (Bioveta, a.s., Česká republika). Telata $(\mathrm{n}=61)$ byla vakcinována intramuskulárně. Intervaly mezi vakcinací a revakcinací byly 3, 5, 7, 10, 14 nebo 28 dnů. Další skupina telat $(\mathrm{n}=16)$ byla vakcinována jedenkrát dvojnásobnou dávkou vakcíny. Protektivní imunita proti experimentální infekci virulentním kmenem Trichophyton verrucosum CCM F-650 byla u zvírrat vyšetřována měsíc po poslední vakcinaci a porovnávána se skupinou nevakcinovaných kontrol $(\mathrm{n}=16)$. Klinické výsledky byly vyhodnoceny a porovnány s použitím vyvážené dvoufaktorové analýzy variance (ANOVA). Úroveň post-vakcinační imunity skotu po revakcinaci byla dostatečná, když byl interval 5, 7, 10, 14 a 28 dnů. Jednorázová aplikace dvojnásobné profylaktické dávky vakcíny a třídenní interval mezi vakcinacemi snížily imunitu a účinnost vakcíny na nevyhovující úroveň. Byly zjištěny statisticky významné rozdíly mezi skupinami telat vakcinovanými v intervalu delším než 5 dnů a skupinou vakcinovanou jednou dvojnásobnou dávkou a skupinou s tř́́denním intervalem mezi vakcinacemi. Úroveň post-vakcinační imunity skotu po revakcinaci v běžně uživaném intervalu 10 - 14 dnů byla stejná jako imunita dosažená při zkrácení intervalu na 5 nebo 7 dnů nebo při jeho rozšśřrení na 28 dnů. Ve veterinární praxi doporučujeme rozšíření intervalu mezi vakcinacemi na 5 - 28 dnů při používání vakcíny Trichoben.

\section{References}

BRATBERG AM, SOLBAKK IT, GYLLENSVAAN C, BREDAHL LK, LUND, A 1999: Experimentelle Challenge-Studie zur Wirksamkeit einer inaktivierten und einer attenuierten Rindertrichophytie-Vakzine. Tierarztl Umsch 54: 519-520

GOLOVINA NP, ZHARKOV II 1984: Adjuvantnye svojstva gelja gidrookisi aljuminija i odnokratnaja immunizacija vakcinoj LTF-130. Veterinarija (Moscow) 5: 34-35

GUDDING R, LUND A 1995: Immunoprophylaxis of bovine dermatophytosis. Can Vet J 36: $302-306$

HEJTMÁNEK M, KOĎOUSEK R, WEIGL E, RYBNIKÁŘ A, VRZAL V, CHUMELA J 1986: Tissue reaction in guinea pigs after intramuscular application of living vaccine against trichophytosis. Acta Univ Palacki Olomuc Fac Med 114: 171-185

RYBNIKÁŘ A, VRZAL V, CHUMELA J 1993: Vaccination of young calves against trichophytosis. Acta Vet Brno 62: 55-61

RYBNIKÁR A, VRZAL V, CHUMELA J 1998: Protective efficacy of vaccines against bovine dermatophytosis after double and single vaccination. Mycoses 41: 83-86

SARKISOV AK 1979: Specifičeskaja profilaktika trichofitii krupnogo rogatogo skota. Veterinarija (Moscow) 1: 40-41

SARKISOV AK, NIKIFOROV LI, PRITULAAS, PETROVICH SV, DZHILAVLJAN HA 1976: Suchaja vakcina LTF-130 protiv striguščego lišaja krupnogo rogatogo skota. VIEV Bull 25: 7-10

SARKISOV AK, OVCINNIKOV RS, LETJAGIN KP, PANIN AN 2000: Vakcina Vermet protiv dermatofitoza krupnogo rogatogo skota. Veterinarija (Moscow) 1: 18-19

WAWRZKIEWICZ K, CHROL M 1977: Badania nad leczeniem i zapobieganiem trychofitozie bydla przy pomocy szczepionki Bovitrichovac. Med Weter 33: 337-340

WAWRZKIEWICZ K, WAWRZKIEWICZ J 1984: Ocena wlasciwosci immunogennych szczepionek zywych i inaktywowanej przeciwko trychofitozie bydla. Med Weter 40: 33-36 
